\title{
ACKNOWLEDGEMENTS
}

\section{REVIEW OF THE LITERATURE: THE PROCESS}

Immediately after the April Congress on Informatics and Education, articles and speeches were obtained as potential publications for the special edition of the Journal. Also, an extensive automated review of the literature was carried out under a grant from DIALOG Information Services, Washington, DC. Mrs Anne Caputo, Programme Manager for the Classroom Instruction Programme, obtained a grant for the search for the International Association of Universities (IAU).

The automated search located 25,703 possible articles for this issue of the Journal, drawn from 44 separate databases from the 350 in the expanding library of the DIALOG Information System. Twenty-one articles were finally identified as material to supplement the Unesco speeches and documentation from the Congress. A normal manual search to cover the documentation needed for the issue would have taken several months. In this instance it took only a few minutes.

The articles were scanned into a wordprocessor using a Hewlett-Packard Scanjet Scanner and Read Right Software produced by OCR, Huntingdon, Pennsylvania. George Reidy, Graduate Assistant at George Washington University assisted in the initial selection of the articles. Mrs Elaine Haddock, Research Associate, carried out the computer searching through DIALOG, performed the scanning of the Unesco speeches and articles from DIALOG, and assisted in the text editing.

The Editors would also like to thank the Technical Horizons in Education Journal for permission to include the articles by Herminia Azinian, Peter Bollerslev, B. Nag, and Tom J. van Weert. Extracts from the monograph Information Technology and the Conduct of Research have been included with the kind permission of the National Science Foundation, Washington, DC.

The Editors would also wish to thank Pan Books Ltd of London for permission to use extracts from a 1980 monograph, North-South: A Programme for Survival, presented by the Independent Commission on International Development Issues, chaired by Willy Brandt. 